\title{
Expandable cylindrical cages in the cervical spine: a review of 22 cases
}

An error appeared in the article by Auguste et al. (Auguste KI, Chin C, Acosta FL, et al: Expandable cylindrical cages in the cervical spine: a review of 22 cases. J Neurosurg Spine 4:285-291, April 2006).

The name of the expandable cylindrical cage used in this study was incorrect. The device actually used was the Ulrich VBR (Ulrich Medical, Ulm, Germany).

The article has been corrected online as of July 29, 2016.

Christopher P. Ames, MD

University of California, San Francisco, CA

INCLUDE WHEN CITING

Published online July 29, 2016; DOI: 10.3171/2016.7.SPINE1615795a.

CAANS, 2016 